\title{
EPISTEMOLOGI EKONOMI ISLAM DAN MAQASID SYARIAH DALAM KURIKULUM EKONOMI ISLAM DI PERGURUAN TINGGI
}

\author{
Selamat Muliadi \\ Fakultas Ilmu Agama Islam, Universitas Islam Indonesia Yogyakarta \\ E-mail: selametmuliadi@gmail.com
}

\begin{abstract}
The Epistemology of Sharia Economy and Maqasid Sharia in Islamic Economics Curriculum in the Higher Education. The potencies and roles of Universities both Islamic Higher Education (PTA) and Public Higher Education (PTU) in providing human resources through Islamic economic and finance learning development that accommodates the competencies of industries demand. Islamic economic as discipline has foundation of epistemology. The main problem in the development of economic and Islamic finance in Indonesia is still the gap between the needs of industry and graduate from college. This study aims to analyze how epistemology and the development Islamic economic and curriculum structure of Islamic economics in universities that teach Islamic economic and what is effective approach to be applied so that graduates can meet the needs of financial industry Islamic economic. The method used in this study is a content analysis is used to explain the depth of the curriculum of Islamic economic in university. Based on the results of the study found that the difference was the presence of Islamic economic learning system in higher education so that graduates produced by universities that teach Islamic economic is still little that can meet the market needs of Islamic financial industry.
\end{abstract}

Keywords: Epistemology, Islamic economics, and Curriculum

Abstrak. Epistemologi Ekonomi Islam dan Maqasid Syariah Dalam Kurikulum Ekonomi Islam di Perguruan Tinggi. Potensi dan peran Universitas baik Pendidikan Tinggi Islam (PTA) dan Pendidikan Tinggi Publik (PTU) dalam menyediakan sumber daya manusia melalui pengembangan pembelajaran ekonomi dan keuangan Islam yang mengakomodasi kompetensi permintaan industri. Ekonomi Islam sebagai disiplin memiliki fondasi epistemologi. Masalah utama dalam pengembangan ekonomi dan keuangan Islam di Indonesia masih kesenjangan antara kebutuhan industri dan lulusan dari perguruan tinggi. Penelitian ini bertujuan untuk menganalisis bagaimana epistemologi dan pengembangan ekonomi Islam dan struktur kurikulum ekonomi Islam di universitas yang mengajarkan ekonomi Islam dan apa pendekatan yang efektif untuk diterapkan sehingga lulusan dapat memenuhi kebutuhan industri keuangan ekonomi Islam. Metode yang digunakan dalam penelitian ini adalah analisis isi yang digunakan untuk menjelaskan kedalaman kurikulum ekonomi Islam di universitas. Berdasarkan hasil penelitian ditemukan bahwa perbedaan itu adalah adanya sistem pembelajaran ekonomi Islam dalam pendidikan tinggi sehingga lulusan yang dihasilkan oleh perguruan tinggi yang 
Islamiconomic: Jurnal Ekonomi Islam

Vol.9 No.2 Juli - Desember 2018

mengajarkan ekonomi Islam masih sedikit yang dapat memenuhi kebutuhan pasar industri keuangan syariah.

Kata Kunci: Epistemologi, Ekonomi Islam, Kurikulum

\section{PENDAHULUAN}

Kalau dirunut dalam sejarah, sesungguhnya telah sepuluh abad sebelum orangorang Eropa menyusun teori-teori tentang ekonomi, telah diturunkan oleh Allah Subhanallahu wa Ta'ala di daerah Arab sebuah analisis tentang ekonomi yang unggul. Analisis ekonomi tersebut tidak hanya mencerminkan keadaan bangsa Arab pada waktu itu, sehingga hanya bermanfaat untuk bangsa Arab saja saat itu, tetapi juga untuk seluruh dunia. Sistem ekonomi tersebut merupakan suatu susunan baru yang bersifat universal, bukan merupakan ekonomi nasional bangsa Arab, sistem ekonomi tersebut dinamakan dengan ekonomi Islam. ${ }^{1}$

Meskipun pembelajaran ekonomi Islam di perguruan tinggi agama Islam (PTAI) telah berlangsung cukup lama, namun sampai saat ini pemebelajarannya belum memiliki pola yang sama. Berbeda halnya dengan pembelajaran ekonomi umum (konvensional) di perguruan tinggi umum (PTU) yang telah mapan dan relatif memiliki bentuk yang baku. Implikasinya adalah pembelajaran ekonomi Islam di PTAI memiliki variasi dan pola yang beragam. Di samping itu, tugas mendesak eksponen ekonomi Islam dan pengelola jurusan/prodi ekonomi Islam saat ini adalah tidak sekedar merumuskan pola pengajaran atau kurikulum studi ekonomi Islam yang baku dan terstandard, tetapi tidak kalah pentingnya adalah memastikan kurikulum yang dirumuskan harus relevan dengan kebutuhan pasar saat ini. Bahkan lebih jauh dari itu, alumni prodi ekonomi Islam harus memiliki etos kewirausahaan yang membuatnya mandiri. ${ }^{2}$

Di dalam sistem pendidikan ekonomi Islam integratif, muatan kurikulum perlu menggambarkan sasaran hendak akan di capai, yang meliputi penguasaan bahasa Arab dan Inggris, penguasaan ilmu dasar kesyariahan, penguasaan ilmu ekonomi umum, penguasaan ilmu ekonomi Islam serta penguasaan metodologi penelitian. Sumber daya manusia merupakan salah satu faktor yang memegang peran strategis dalam pengembangan ekonomi Islam, termasuk pengembangan industri keuangan syariah. Akan tetapi sampai saat ini, secara keilmuan ekonomi Islam masih mencari 
Selamat Muliadi: Epistemologi Ekonomi Islam...

bentuk yang kokoh, termasuk di dalam pengembangan dan pembentukan sumber daya manusia. ${ }^{3}$

Ilmu ekonomi Islam dihadapkan dengan berbagai tugas dan tantangan. Pertama, merumuskan konsep perilaku ideal agen-agen ekonomi berdasarkan nilai-nilai Islam (normative) dan kemungkinan efek bagi perekonomian. Kedua, mengevaluasi dan menganalisis perilaku ideal agen-agen ekonomi (positivism) dalam perekonomian. Ketiga, membandingkan dan menjelaskan ketimpangan yang mungkin terjadi di antara perilaku ideal dan perilaku riil. Keempat, adalah merumuskan strategi terbaik untuk mengarahkan perilaku agen-agen ekonomi, sehingga dapat mendekati dan mencapai perilaku ideal yang sesuai dengan nilai-nilai Islam.

Dalam rangka mewujudkan sistem ekonomi Islam dan maqasid syariah yang mampu menghantarkan masyarakat global ke arah lebih sejahtera, kerja keras ekonom dan agamawan sangat dituntut untuk merumuskan pendekatan dan metode multi dimensi. Metode yang bukan saja sebatas ilmu mengajarkan etika dan nilai, tetapi juga menghasilkan postulat-postulat brilian untuk kesejahteraan dunia. Pada titik inilah pentingnya maqasid syariah sebagai koridor dasar untuk istinbat hukum ekonomi Islam. Dengan demikian, diharapkan akan ditemukan satu konsep ekonomi Islam yang ideal, baik dalam teori maupun praktik untuk diterapkan sebagai sistem ekonomi yang global, tidak bertentangan dengan al-Qur'an dan Hadits, tetap seirama dengan tuntutan zaman semakin kompleks, variatif serta dapat mereda pertentangan yang tengah terjadi di dalam praktek ekonomi Islam itu sendiri.

Berdasarkan latar belakang di atas, fokus utama dari tulisan ini adalah begaimana epistemologi ekonomi Islam dan pengembangan di dalam kurikulum ekonomi Islam di perguruan tinggi dan pendekata yang efektif untuk diterapkan agar lulusannya dapat memenuhi kebutuhan industri keuangan ekonomi Islam.

Pendekatan dalam penelitian ini adalah kualitatif deskriptif. Teknik analisis tyang digunakan adalah content analysis (analisis isi). Analisis isi secara sederhana diartikan sebagai metode untuk mengumpulkan dan menganalisis muatan dari sebuah teks. Teks dalam penelitian ini berupa struktur kurikulum ekonomi Islam yang diterapkan pada perguruan tinggi Islam. Content analysis merupakan penelitian yang bersifat pembahasan mendalam terhadap isu suatu informasi tertulis atau tercetak dalam media massa. Content analysis merupakan metode penelitian yang 
Islamiconomic: Jurnal Ekonomi Islam

Vol.9 No.2 Juli - Desember 2018

$\overline{\text { digunakan untuk mengetahui simpulan dari sebuah teks atau dengan kata lain adalah }}$ metode penelitian yang ingin mengungkap gagasan penulis termanifestasi maupun yang laten. Pemahaman dasar dari content analysis adalah banyak kata yang dapat diklasifikasikan ke dalam kategori yang lebih kecil. Setiap kategori dibuat berdasarkan kesamaan makna kata dan kemiripan makna kata dari setiap teks. Dengan asumsi itu, akan dapat mengetahui fokus dari peneliti, pembuat teks dan pembicara dengan menghitung jumlah kategori yang ada dalam teks tersebut.

\section{PEMBAHASAN}

\section{Definisi Ilmu Ekonomi Islam}

Memahami makna ekonomi di dalam Islam dimulai dari pelacakan kata ekonomi (al-iqtishad). Dalam literatur Arab disebutkan al-qashd (ekonomis), berarti kelutusan cara dan juga bermakna adil ataupun keseimbangan. Kata al-iqtishad kalau digandengkan dengan al-ilm menjadi ilm al-iqtishad berarti ilmu yang berkaitan dengan ekonomi. Menurut Umar Chapra, ilmu ekonomi Islam adalah sebagai cabang ilmu pengetahuan yang berupaya membantu mewujudkan kesejahteraan bagi manusia melalui alokasi dan distribusi sumber-sumber daya yang sejalan dengan tujuan-tujuan syariah (maqasid al-syariah). Upaya untuk meningkatkan kesejahteraan manusia menjadi target semuanya dapat membantu mengarahkan dirinya pada cakrawala pengetahuan yang luas, baik dalam dataran teoritis maupun praktis. Fokus ilmu ekonomi adalah mewujudkan kesejahteraan manusia. Semua sektor kehidupan manusia harus berinteraksi secara signifikan dengan ekonomi untuk mewujudkan kesejahteraan itu. ${ }^{4}$

Namun permasalahannya, kesejahteraan di dalam masyarakat tidak mesti ada, karenanya harus diciptakan. Dalam mewujudkan kesejahteraan manusia ada empat tugas yang harus diemban oleh ekonomi Islam, yaitu: pertama, ilmu ekonomi Islam harus mempelajari perilaku sebenarnya dari masing-masing individu, kelompok, perusahaan, pasar dan pemerintah. Kedua, ilmu ekonomi Islam harus mempertimbangkan nilai-nilai Islam dan menganalisis secara ilmiah dampaknya terhadap selera dan preferensi konsumen dan perilaku individu. Semuanya itu berorientasi pada nilai-nilai moral yang dapat mengarah kepada terbentuknya upaya pencapaian tujuan kemanusiaan. Ketiga, ilmu ekonomi Islam harus mampu 242 
Selamat Muliadi: Epistemologi Ekonomi Islam...

menjelaskan bahwa pranata ekonomi yang dimilikinya jelas berbeda dengan pranata ekonomi lainnya. Keempat, ilmu ekonomi Islam harus bisa memberikan kontribusi positif, baik menyangkut teori maupun praktik guna menghadapi perubahan sosialekonomi dan politik, yaitu strategi yang dapat membantu mengarahkan semua pelaku pasar (penjual, pembeli dan terkait dengan aktivitas pasar) yang dapat mempengaruhi alokasi dan distribusi sumber daya. Keempat tugas tersebut tidak hanya berguna untuk menganalisis sebab-sebab utama dari permasalahan yang dihadapi oleh negara-negara Muslim, tetapi juga dapat mengarahkan umat Islam kepada penentuan sikap, permasalahan dapat diselesaikan tanpa mengesampingkan maqasid al-syariah. ${ }^{5}$

\section{Maqasid Syariah Sebagai Koridor Pengembangan Ilmu dan Norma Ekonomi} Islam

Maqasid syariah berasal dari bahasa Arab, yaitu maqasid adalah jamak dari maqshud (tujuan atau sasaran). Secara terminologi, maqasid syariah dapat diartikan sebagai tujuan syariah. Bagi sebagian ulama, maqasid juga diartikan sebagai "mashlahah".6 Maqasid syariah menjelaskan hikmah di balik aturan syariat Islam. Maqasid syariah dapat dianggap juga sebagai sejumlah tujuan yang dianggap Ilahi dan konsep akhlak yang melandasi proses at-Tasyri' al-Islamiy, seperti prinsip keadilan, kehormatan manusia, kebebasan berkehendak, kesucian dan lain sebagainya. Maqasid syariah merupakan tema sangat penting, namun sering terlupakan. Secara umum, syariah ditujukan untuk memperoleh kemaslahatan baik bagi individu maupun kelompok dan aturan-aturannya akan di konstruksikan untuk melindungi kemaslahatan dan memungkinkan manusia untuk memperoleh kehidupan yang sempurna di muka bumi. ${ }^{7}$

Untuk memperbaiki kekurangan pada orientasi individualistik klasifikasi maqasid klasik, para ulama kontemporer telah memperluas konsep maqasid, meliputi jangkauan yang lebih luas seperti masyarakat, bangsa bahkan manusia secara umum. Perluasan dari jangkauan maqasid syariah memberi kesempatan bagi para ulama kontemporer untuk merespons tantangan global dan membantu merealisasikan maqasid menjadi rencana-rencana praktis untuk reformasi dan pembaharuan. Dalam rangka untuk merevisi maqasid klasik oleh para ulama kontemporer berhasil 
Islamiconomic: Jurnal Ekonomi Islam

Vol.9 No.2 Juli - Desember 2018

mengemukakan maqasid universal baru, yang dideduksi langsung dari teks-teks suci, bukan dari literatur warisan madzhab fiqh Islami.

Mashlahah merupakan sebuah konsep yang sangat kuat, meliputi seluruh aspek kehidupan manusia, baik ekonomi, individu dan kolektif sangat relevan dengan pencapaian kesejahteraan sosial dan masyarakat sesuai dengan tujuan syariah. Poin utamanya adalah bahwa Islam menentukan tujuan utama hidup manusia. Segala hal yang mendukung terwujudnya tujuan ini disebut dengan mashlahah, sedangkan untuk kebalikannya disebut dengan mafaashid. Konsep mashlahah juga diterapkan dalam prilaku konsumen dimana manusia cenderung untuk memilih brang dan jasa yang memberikan mashlahah yang maksimum. Hal ini sesuai dengan rasionalitas Islam, bahwa setiap agen ekonomi ingin meningkatkan mashlahah yang diperolehnya. ${ }^{8}$

Masuknya teori maqasid syariah dalam wilayah ekonomi Islam dapat ditemukan secara langsung dalam landasan etika. Para pelaku ekonomi tidak hanya dituntut untuk dapat menguasai sumber-sumber ekonomi yang strategis, tetapi juga memanfaatkannya untuk kepentingan umat dengan mengacu pada kemaslahatan dharuriyah, hajiyyah dan tahsiniyyah. Bagi kajian ekonomi, teori maqasid syariah adalah salah satu usaha logis yang wajib diterapkan sebagai konsekuensi pemahaman ekonomi berkeadilan di satu sisi dan berkebutuhan di sisi lain. Selain itu, akan dipahami kemaslahatan sebagai kebutuhan manusia, termasuk juga dikaitkan dengan lapangan ekonomi akan mengikuti teori-teori ekonomi yang sesuai dengan pencapaian visi dan misi Islam. Survei-survei dari perkembangan sosial dan kondisi real dalam masyarakat serta inferensi tekstual harus dijadikan acuan dalam menentukan strategi ekonomi.

Pengetahuan tentang maqasid syariah adalah hal yang sangat penting, untuk mengerti dan memahami agar dapat dijadikan sebagai alat bantu dalam memahami redaksi al-Qur'an dan Sunnah, membantu menyelesaikan dalil yang saling bertentangan (ta'arud al-adillah) dan yang sangat penting lagi adalah untuk menetapkan suatu hukum dalam sebuah kasus yang ketentuan hukumnya tidak tercantum dalam al-Qur'an dan Sunnah jika menggunakan kajian semantik (kebahasaan). Metode istinbat al-hukm dengan menggunakan qiyas (analogi), istihsan dan maslahah al-mursalah merupakan metode yang bisa dipakai dalam 244 
Selamat Muliadi: Epistemologi Ekonomi Islam...

pengembangan hukum Islam dengan menggunakan maqasid syariah sebagai dasarnya. ${ }^{9}$

\section{Metodologi Ilmu Ekonomi Islam}

Kajian metodologi ilmu ekonomi Islam dibagi menjadi dua tingkat, pertama, kajian metodologi dalam penggalian asas-asas ekonomi Islam. Kedua, kajian metodologi dalam rangka penyusunan bangunan ilmu ekonomi Islam, kajian tentang langkah-langkah yang ditempuh. Kajian metodologi yang pertama tidak dapat dipisahkan dari kajian epistemologi yang berkembang dalam sejarah pemikiran Islam. Dalam perspektif epistemologi Islam, wahyu menjadi bagian dari hubungan sistematik, yakni menjadi salah satu sumber pengetahuan yang penting, pengetahuan wahyu menjadi pengetahuan apriori. Wahyu menempati posisi sebagai salah satu pembentuk konstruk mengenai realitas, sebab wahyu memberikan pedoman bagi tindakan seorang Muslim. ${ }^{10}$

Framework kerja metodologis berupa langkah-langkah penyusunan ilmu ekonomi Islam, diantaranya: Langkah pertama: identifikasi fungsi dasar dari ekonomi, yaitu produksi, konsumsi dan distribusi tanpa memandang perbedaan ideologi. Langkah kedua: perumusan asas-asas ekonomi yang memiliki makna universal, abadi dan diterapkan dalam semua fungsi faktor ekonomi. Disinilah tempat kerja metodologi pertama kali dilakukan. Metode yang digunakan dalam perumusan asas ini adalah metode induktif tematik. Langkah ketiga: identifikasi cara operasi yang kemudian disusun dalam bentuk konsep yang praktis dengan variabel-variabel yang berakar pada syariah. Tetapi konsep ini tidak berarti bersifat abadi, masih terbuka untuk direkonstruksi tetap berpegang teguh pada prinsip-prinsip universal di atas. Komitmen selalu terbuka bagi kemungkinan terjadinya rekonstruksi dan pengembangan konsep ekonomi Islam yang sudah dirumuskan dengan tetap bertumpu pada nilai-nilai universal dan kondisi empiris masyarakat. Langkah keempat: menguraikan barang dan jasa sebagai instrument asas-asas dibangun di atas dengan mempertimbangkan kondisi riil dari sosio-ekonomi masyarakat setempat. Dalam hal ini, teori kebenaran pragmatis dan positifis diperlukan untuk membimbing perumusan konsep berpikir rasional-empiris, yakni dengan melihat kenyataan yang terjadi dalam masyarakat dijadikan acuan dalam menentukan barang dan jasa yang 
Islamiconomic: Jurnal Ekonomi Islam Vol.9 No.2 Juli - Desember 2018

relevan. Langka kelima: menggunakan teori kebenaran interkontekstualitas (the intercontextuality theory of truth), yakni beranggapan bahwa kebenaran yang muncul adalah kebenaran setelah adanya proses dialektika antara realitas dan fakta. Bentuk kebenaran ini berupa pernyataan yang muncul setelah terjadinya sebuah peristiwa. Sumber otoritas dalam kerangka ilmu ekonomi Islam adalah sumber-sumber yang ditelah dirumuskan, baik dalam bentuk pemahaman fiqh (normatif) maupun pemahaman substantif (kemaslahatan umum, prinsip dan asas). ${ }^{11}$

Perjuangan panjang dari ilmu ekonomi konvensional untuk mengangkat derajatnya agar sejajar dengan ilmu-ilmu alam menunjukkan bahwa kelahiran metodologi ekonomi terjadi setelah ilmu ekonomi tumbuh dewasa. Dengan kata lain, keberadaan dari metodologi dalam ekonomi tidak lain merupakan upaya justifikasi atau pengabsahan ilmu ekonomi. Justru disinilah sebenarnya ekonomi konvensional mengalami kesulitan mengembangkan diri. Kondisi ini disebabkan karena ekonomi telah mendeklarasikan diri sebagai science yang menutup diri dari nilai etika dan moral bahkan agama, karena telah menetapkan pilihannya sendiri berupa nilai materi. Sandaran nilai mereka adalah ilmu pengetahuan yang dibangun dari proses hypothetico deductive. Dengan penolakannya terhadap divine knowledge, menjadikan ekonomi konvensional tidak memiliki hard core universal yang dapat dijadikan sebagai rujukan atau kriteria untuk menilai mana yang benar dan salah, mana yang bisa diterima dan ditolak. ${ }^{12}$

Berbeda dengan konvensional, ilmu ekonomi Islam telah lebih dahulu berusaha membangun metodologi sebelum ilmu tersebut mencapai kemapanan. Ilmu pengetahuan ('ilm atau fiqh) pertama kali digunakan umat Islam dalam kaitannya dengan pengetahuan tentang wahyu, tradisi serta maknanya. Dengan cara ini, ilmu mulai memperoleh makna teknis ketika akan diterapkan dalam pengetahuan tentang hukum Tuhan. Dalam hal ini, ilmu dapat diartikan sebagai pengetahuan diperoleh melalui istidlal (melalui bukti). Istidlal mengisyaratkan pengamatan melalui ekspriment, pengukuran dan pengamatan lebih lanjut. Dalam perkembangannya terjadi perbedaan antara istiqra (investigasi terhadap data mentah) dengan cara istinbath (menyimpulkan isi data).

Pertama, identik dengan metode empiris induktif, sedangkan yang kedua identik dengan metode analisis. Fiqh muamalah merupakan salah satu produk awal dari 246 
Selamat Muliadi: Epistemologi Ekonomi Islam...

usaha fuqaha Muslim untuk menerjemahkan nas dan tradisi kenabian ke dalam bentuk praksis (dalam bidang perekonomian). Ratusan kitab fiqh telah disusun oleh fuqaha dalam semangat yang sama, meskipun sebenarnya secara general kajian dari kitab tersebut dapat diklasifikasikan ke dalam empat mazhab saja. Suatu hal yang menarik bahwa kajian-kajian hukum di dalam kitab-kitab tersebut lebih banyak didasarkan kepada kasus-kasus imajinatif yang digagas sendiri oleh fuqaha. Sebagian besar dari kasus-kasus tersebut belum pernah atau bahkan tidak mungkin terjadi dalam realitas keseharian. Ini menunjukkan bahwa dalam tradisi keilmuan Islam, para fuqaha lebih dahulu membangun metodologi sebelum ilmu itu terbentuk.

\section{Epistemologi Ekonomi Islam}

Seluruh dari disiplin ilmu pengetahuan memiliki landasan epistemologi. Dengan kata lain sebuah ilmu, baru dapat dijadikan sebagai suatu disiplin ilmu jika ia memenuhi syarat-syarat ilmiah (scientific). Epistemologi adalah cabang filsafat yang membahas secara mendalam segenap proses untuk memperoleh ilmu pengetahuan. Epistemologi ini pada umumnya disebut filsafat pengetahuan. Secara etimologi, epistemologi berasal dari kata Yunani, yaitu episteme dan logos. Episteme berarti pengetahuan, sedangkan logos berarti teori, uraian atau alasan. Jadi, epistemologi dapat diartikan sebagai teori tentang pengetahuan. Epistemologi pada hakikatnya membahas tentang filsafat pengetahuan yang berkaitan dengan asal-usul pengetahuan, bagaimana memperoleh pengetahuan (metodologi) dan kesahihan (validitas) pengetahuan tersebut. Epistemologi atau teori pengetahuan merupakan cabang filsafat yang berurusan dengan hakikat dan lingkup pengetahuan. ${ }^{13}$

Dari sudut pandang epistemologi dapat diketahui bahwa ilmu ekonomi diperoleh melalui pengamatan (empirisme) terhadap gejala sosial masyarakat dalam memenuhi kebutuhan hidupnya. Pengamatan yang dilakukan kemudian digeneralisasi melalui premis-premis khusus untuk mengambil kesimpulan yang bersifat umum. Perubahan yang diamati dalam sistem produksi dan distribusi barang dan jasa, dijadikan sebagai teori umum yang dapat menjawab berbagai masalah ekonomi. Pemikiran Abu Yusuf tentang teori supply dan demand merupakan hasil observasi di tengah masyarakat pada masanya. Ibnu Khaldun mengkaji problem ekonomi masyarakat dan negara secara empiris. Teori tersebut diperoleh dari 
Islamiconomic: Jurnal Ekonomi Islam

Vol.9 No.2 Juli - Desember 2018

pengalaman dan fakta di lapangan yang diteliti secara konsisten oleh para ahli ekonomi. Berdasarkan cara kerja yang demikian, penemuan teori-teori ekonomi di kelompokkan ke dalam context of discovery. ${ }^{14}$

Jika diterapkan dalam ilmu ekonomi, maka seluruh transaksi bisnis pada dasarnya diperbolehkan jika tidak ada nash yang mengharamkannya. Pelarangan terhadap praktik bunga dan riba dalam perbankan konvensional disebabkan adanya beberapa nash yang mengharamkannya. Cara kerja seperti ini di dalam filsafat ilmu dikenal dengan istilah context of justification. Ilmu ekonomi Islam kontemporer disusun dengan mengikuti aturan main (rule of game) syariah dan kaidah ilmiah keilmuan modern. Nilai-nilai Islam merupakan sumber informasi dan panduan (guidence) di dalam proses perkembangan ilmu, sehingga aspek ontologis, epistemologis dan aksiologis selalu dalam koridor Islam. ${ }^{15}$

Secara ontologis, ilmu ekonomi Islam membahas dua disiplin ilmu yang secara bersamaan. Kedua disiplin ilmu itu adalah ilmu ekonomi murni dan ilmu fiqh muamalah. Dalam operasional, ilmu ekonomi Islam akan selalu bersumber dari kedua disiplin ilmu tersebut. Persoalan ontologis yang muncul adalah bagaimana memadukan antara pemikiran ilmu ekonomi dengan pemikiran fiqh yang terdapat dalam fiqh muamalah. Persoalan ini muncul mengingat bahwa sumber ilmu ekonomi Islam adalah pemikiran manusia sedangkan sumber fiqh maumalah adalah wahyu yang didasarkan pada petunjuk al-Qur'an dan Hadits. Perbedaan sumber ilmu pengetahuan ini menyebabkan munculnya perbedaan penilaian terhadap problematika ekonomi manusia. Fiqh muamalah diperoleh melalui penelusuran langsung terhadap al-Qur'an dan Hadits oleh para fuqaha. Melalui kaidah-kaidah ushuliyah dapat merumuskan beberapa aturan yang harus dipraktikkan dalam kehidupan ekonomi umat. Rumusan tersebut didapatkan dari hasil pemikiran (rasionalisme) melalui logika deduktif. Premis mayor yang disebutkan dalam wahyu dapat dijabarkan melalui premis-premis minor untuk mendapatkan kesimpulan yang baik dan benar. 16

Aksiologi membahas tentang tujuan ilmu pengetahuan, dengan kata lain untuk apa ilmu yang telah disusun akan digunakan. Kajian aksiologis ekonomi Islam adalah membicarakan ekonomi Islam dari segi nilai dan manfaat dari ilmu. Dengan pendekatan aksiologis, diperlukan untuk melihat fungsi dan kegunaan ilmu ekonomi 
Selamat Muliadi: Epistemologi Ekonomi Islam...

Islam dalam menyelesaikan berbabagai persoalan yang dihadapi manusia dalam kehidupan sehari-hari. Tujuan ilmu ekonomi Islam adalah untuk mencapai falah atau kebahagiaan dunia-akhirat. Ada dua pendekatan utama yang digunakan dalam pengembangan dari ilmu ekonomi Islam, yaitu deduktif dan induktif.

Pendekatan deduktif diawali dengan mengekstraksi inti dari ajaran Islam menjadi elemen-elemen teori ekonomi Islam. metode berpikir deduktif adalah metode berpikir yang menerapakan hal-hal yang umum terlebih dahulu untuk seterusnya dihubungkan dalam bagian-bagian yang khusus. Metode qiyas dalam hal fiqh sesungguhnya mirip dengan metode deduktif ini. Membuat kesimpulan umum dari pernyataan khusus. Metode induktif atau disebut juga dengan metode empiris, adalah menarik suatu kesimpulan dari yang bersifat khusus menjadi kesimpulan yang bersifat umum. Contoh-contoh kongkrit dan fakta diuraikan terlebih dahulu, kemudian dirumuskan menjadi suatu kesimpulan. Pada metode induktif, data dikaji melalui proses yang berlangsung dari fakta.

\section{Rekonstruksi Pembelajaran Ekonomi Islam di PTAI}

Pembelajaran ekonomi Islam dengan berbagai macam konsentrasi di PTAI telah berlangsung lebih kurang satu dasawarsa. Akan tetapi, pembelajaran masih dapat digolongkan sebagai studi yang baru di dunia lembaga pendidikan tingga agama Islam khususnya di PTAI. Hal ini dapat dilihat pada beberapa model yang dikembangkan oleh PTAI yang membuka pembelajaran ekonomi Islam. Model-model yang ada dengan berbagai variasinya tersebut secara garis besar dapat digolongkan ke dalam dua model, yaitu:

Pertama, lebih menonjolkan pengajaran tentang fiqh muamalah dan keilmuan syariah, hanya memberikan pengajaran tentang teori-teori ekonomi secara global dengan pendekatan konseptual saja. Sementara itu, ilmu ekonomi dan perbankan konvensional yang merupakan basis ilmu ekonomi itu sendiri kurang mendapatkan porsi yang mencukupi. Demikian juga dengan ilmu dan teknologi sebagai pendukung utama ilmu ekonomi, seperti matematika, statistik dan ekonometrik kurang mendapatkan tempat. Hal ini akan mengakibatkan terjadinya pemahaman yang kurang tepat tentang ekonomi Islam secara utuh dan tidak dapat diandalkan serta 
Islamiconomic: Jurnal Ekonomi Islam Vol.9 No.2 Juli - Desember 2018

tidak dapat dianggap sebagai disiplin ilmu yang terukur menurut kriteria pembelajaran yang sinergis antara contents, condaucts, contexts dan contours.

Kedua, lebih menonjolkan pengajaran tentang ekonomi konvensional dengan semua tingkatan pendekatannya, tetapi sedikit memberikan pembelajaran tentang teori ekonomi Islam. Pembelajaran tentang ushul fiqh, fiqh muamalah dan falsafah hukum Islam kurang mendapatkan porsi di dalamnya. Barangkali dalam kondisi tertentu, keadaan ini dirasa mencukupi ketimbang model pertama, karena basis keilmuan ekonomi yang dikuasai dianggap mencukupi, sedangkan tentang teori ekonomi Islam dianggap hanya merupakan tambahan yang tidak terlalu mendasar. Namun, pada saat tertentu kondisi ini merupakan kelemahan yang menonjol apabila dihadapkan kepada masalah-masalah perbedaan konsep tentang hakikat ekonomi konvensional dan Islam. Dalam dataran pengembangan kondisi ini tidak akan dapat menolong alumninya untuk mengadakan langkah-langkah kreatif dalam mengembangkan ilmu ekonomi Islam yang disesuaikan dengan kebutuhan masyarakat. ${ }^{17}$

Dua model tersebut di atas menunjukkan bahwa pembelajaran ekonomi Islam di PTAI sedang dalam proses pencarian bentuk. Namun, menegasikan satu model dan mangafirmasi model lain adalah suatu sikap yang tidak bijak. Akan tetapi, lebih baik memberi ruang yang sama kepada kedua model tersebut untuk mengembangkan studi ekonomi Islam yang relevan dengan kebutuhan pasar saat ini. PTAI perlu merekonstruksi model pembelajarannya, yakni dengan berusaha memberikan penekanan kepada kedua model di atas. Penekanan terhadap teori-teori ekonomi secara umum harus mendapatkan prioritas, karena hal itu menjadi dasar dan fondasi bagi setiap ekonom, termasuk ekonom Islam sehingga dapat menolong alumninya mengadakan langkah kretaif dalam mengembangkan ilmu ekonomi Islam yang sesuai dengan kebutuhan masyarakat.

Kebutuhan dan tuntutan masyarakat saat ini semakin kompleks, karena itu program-program studi yang di tawarkan oleh PTAI juga dapat dan sangat mungkin bervariasi. Namun, program studi ekonomi Islam dapat mengadopsi pola yang telah di kembangkan di PTU. Pola tersebut meliputi, program studi akuntansi, managemen keuangan, dan ekonomi pembangunan, kemudian dapat direkonstruksi menjadi program studi akuntansi syariah, managemen keuangan syariah, dan ekonomi 250 
Selamat Muliadi: Epistemologi Ekonomi Islam...

pembangunan syariah. Program-program studi ini dapat mengembangkan dirinya melalui konsentrasi-konsentrasi yang dibutuhkan, tentu dengan mengingat berbagai hal, minat masyarakat pengguna, ketersediaan dari sumber daya manusia dan lain sebagainya.

\section{Kendala-Kendala Rekonstruksi Pembelajaran Ekonomi Islam di PTAI}

Permasalahan yang dihadapi oleh perguruan tinggi termasuk di dalamnya PTAI dalam mengembangkan pembelajaran ekonomi Islam terkait dengan kompetensi lulusan dihasilkan, yaitu terletak pada tenaga pengajar, kurikulum, kompetensi inti, kondisi kekinian pada pembelajaran ekonomi Islam, sarana praktikum, sistem informasi dan referensi ekonomi Islam yang masih minim dan kebijakan pimpinan. Kendala yang dihadapi oleh PTAI dalam merekonstruksi pembelajaran ekonomi Islam agar dapat menghasilkan kompetensi lulusan yang dibutuhkan pasar sebagai berikut:

Pertama, tenaga pengajar adalah kunci penting pada perguruan tinggi. Tenaga pengajar ekonomi Islam pada PTAI bersumber dari alumni jurusan atau prodi ekonomi Islam PTAI yang memiliki keunggulan penguasaan aspek ilmu-ilmu kesyariahan, tetapi memiliki kelemahan pada penguasaan aspek ekonomi dari alumni fakultas ekonomi PTU yang memiliki keunggulan pada penguasaan aspek ekonomi, tetapi memiliki kelemahan pada penguasaan aspek ilmu-ilmu kesyariahan. Oleh karena itu, hal yang paling penting dilakukan meskipun sulit diwujudkan adalah menyediakan tenaga pengajar integratif mampu memadukan antara aspek ilmu-ilmu syariah dengan aspek ilmu ekonomi.

Kedua, kurikulum dan kompetensi inti. Hingga saat ini belum ada kebijakan di tingkat nasional dalam hal standarisasi kurikulum inti ekonomi Islam. Kurikulum inti yang dimaksudkan disini adalah sejumlah mata kuliah wajib diberikan untuk menghasilkan kompetensi utama menjadi seorang sarjana ekonomi Islam, yang disepakati oleh elemen perguruan tinggi dan asosiasi profesi yang kompeten di bidang ekonomi Islam. Industri keuangan syariah membutuhkan lulusan siap pakai dan langsung bekerja tanpa harus dilakukan pendidikan, pelatihan dan adaptasi yang terlalu lama, sehingga dibutuhkan biaya untuk up grading karyawan baru cukup tinggi. Akan tetapi, industri keuangan syariah menilai bawah masih terjadi mis-match antara kurikulum yang disusun oleh perguruan tinggi dengan kebutuhan pasar. 
Islamiconomic: Jurnal Ekonomi Islam

Vol.9 No.2 Juli - Desember 2018

Ketiga, kondisi kekinian pada pembelajaran ekonomi Islam. Hal ini merupakan masalah struktur akademik posisi kajian ekonomi Islam. Masalah ini dapat dilihat pada sebagian besar dari PTAI yang telah membuka program studi ekonomi Islam dengan nama dan pemahaman berbeda-beda. Misalnya, prodi muamalah, prodi ekonomi Islam, prodi keuangan syariah dan lain sebagainya. Perbedaan struktur akademik ini menjadi salah satu kendala dalam memenuhi kebutuhan sumber daya ekonomi Islam sesuai dengan kompetensi diharapkan, yaitu sumber daya manusia integratif.

Keempat, sarana praktikum, sistem informasi dan akses referensi untuk ekonomi Islam yang masih minim. Sarana dan prasarana memadai berkorelasi positif dengan efektivitas kegiatan belajar mengajar pada ekonomi Islam pada perguruan tinggi. Karena itu, jika sarana praktikum, sistem informasi dan akses referensi ekonomi Islam yang dimiliki oleh PTAI tidak memadai, maka akan menjadi salah satu kendala dalam proses pembelajaran ekonomi Islam di PTAI tersebut. Akibatnya, tidak dapat melahirkan output yang dapat berkompetisi dan memenuhi keinginan pasar. Karena itu, sarana dan prasarana yang mendukung proses pembelajaran ekonomi Islam di PTAI harus memadai.

Kelima, kebijakan pimpinan dan kultur akademik, pembelajaran ekonomi Islam perguruan tinggi sangat didukung oleh pimpinan dan kultur akademiknya. Dengan demikian jika pimpinan PTAI memahami bahwa pembelajaran ekonomi Islam yang baik adalah dapat menghasilkan output kompeten dan diinginkan oleh pasar maka akan mendukung dilakukan rekonstruksi pembelajaran ekonomi Islam sesuai yang dikehendaki pasar dan tentunya hal ini harus didukung pula kultur akademik di PTAI tersebut.

\section{Langkah Strategis Pengembangan Kurikulum Ekonomi Islam}

Untuk mencetak sumber daya manusia yang profesional dan berkualitas, menguasai sistem ekonomi Islam dan terampil dalam mengelola industri-industri keuangan dan bisnis Islam sangat ditentukan oleh kurikulum dari suatu institusi pendidikan. Dalam merespon kebutuhan di atas, berbagai perguruan tunggi yang ada di Indonesia menawarkan pengajaran ekonomi Islam. Pengajaran ekonomi Islam yang ada sekarang ini dapat digolongkan menjadi beberapa kategori, yaitu 
Selamat Muliadi: Epistemologi Ekonomi Islam...

Kategori pertama, membuka program studi perbankan syariah di fakultas syariah/ilmu agama Islam di PTAI maupun PTAIN. Pola pendekatan kurikulum yang menjadi acuan pengajaran program dari studi tersebut diterapkan bobotnya terlalu mengandalkan pengajaran ilmu-ilmu syariah tetapi kurang mengandalkan pengajaran ilmu ekonomi dan perbankan modern. Hal ini terjadi karena jurusan yang diberikan masih dalam lingkup fakultas syariah/ilmu agama Islam. Boleh jadi kelemahan ini merupakan akibat sifat alami dari pendidikan PTAI/PTAIN yang memang terfokus pada pengajaran ilmu-ilmu agama (Islamic studies). Porsi pengajaran ilmu ekonomi dan perbankan konvensional kurang dibarengi dengan pengajaran iptek (ilmu pengetahuan dan teknologi) seperti, matematika dan statistika.

Kategori kedua, memasukkan konsentrasi kajian perbankan Islam dalam fakultas ekonomi universitas umum. Berbeda dari kajian dan pengajaran yang di tawarkan oleh PTAI, fakultas ekonomi tetap mengajarkan semua teori ilmu ekonomi konvensional dengan semua tingkatan pendekatan. Dengan kata lain, kurikulum nasional yang berlaku bagi seluruh fakultas berjalan tetap seperti biasa, kemudian mahasiswa diberikan konsentrasi kepada perbankan Islam. pendekatan ini memiliki kelemahan, pengajaran ushul fiqh, fiqh muamalah dan falsafah hukum Islam tidak memadai. Ketiadaan subjek-subjek mengakibatkan mahasiswa tidak memiliki pandangan yang benar tentang konsep-konsep, teori dan landasan filosofi ekonomi Islam yang sebenarnya, justru dapat diturunkan dari mata kuliah tersebut. Mahasiswa pada gilirannya tidak dapat membedakan secara tegas perbedaan konseptual beberapa hal dalam bidang ekonomi, antara konsep Islam dan konvensional. Pada tingkat intelektual yang tinggi, ketiadaan mata kuliah ini akan menghambat mahasiswa untuk dapat melakukan langkah-langkah kreatif dan pengembangan ekonomi Islam yang dibutuhkan masyarakat sebagai tantangan perkembangan zaman.

Kategori ketiga, pengajaran ekonomi Islam di bawah naungan fakultas ekonomi Universitas Islam (swasta). Posisi ini tampaknya menjadi keunggulan tersendiri untuk mengembangkan ilmu ekonomi Islam di lingkungan perguruan tinggi. Jika kategori pertama meletakkan pengajaran ekonomi Islam di bawah payung fakultas ilmu agama Islam, sementara kategori kedua sebagai naungan konsentrasi perbankan Islam, kategori ketiga dipandang sebagai tempat untuk pengembangan dan 
Islamiconomic: Jurnal Ekonomi Islam

Vol.9 No.2 Juli - Desember 2018

pengajaran ekonomi Islam pada sebuah fakultas. Penguasaan terhadap fiqh muamalah dan maqasid syariah kurang diperhatikan bukan saja di fakultas ekonomi Universitas Islam swasta melainkan juga pada fakultas ilmu agama Islam. Padahal penguasaan terhadap materi ini sangat dibutuhkan ketika mahasiswa berhasil menjadi pemerhati, pelaku dan praktisi bisnis di lapangan.

Dengan demikian, pembelajaran ideal yang dapat dilakukan dengan cara pengembangan sistem pendidikan integratif. Muatan kurikulum menggambarkan sasaran-sasaran yang hendak dicapai meliputi:

1. Penguasaan bahasa Arab dan bahasa Inggris.

2. Penguasaan ilmu-ilmu dasar kesyariahan, seperti qawaid fiqhiyyah, ushul fiqh dan fiqh muamalah.

3. Penguasaan ilmu ekonomi Islam.

4. Penguasaan ilmu ekonomi umum termasuk keuangan dan akuntansi.

5. Penguasaan metodologi penelitian (tools of analysis), baik penelitian kualitatif maupun kuantitatif sehingga outputnya adalah sumber daya manusia yang memiliki kapabilitas, kompetensi dan keilmuan yang luas baik dalam ilmu syariah maupun ilmu ekonomi.

Dalam pengembangan kurikulum, setidaknya harus memiliki kurikulum berbasis kompetensi yang memadukan antara ilmu syariah dan ilmu umum, serta mengintegrasikan antara teori dengan praktik yang secara berkelanjutan. Dengan pengembangan ekonomi Islam melalui Perguruan Tinggi yang diharapkan akan melahirkan para sarjana ekonomi Islam yang memiliki skill baik dalam bidang syariah maupun ilmu-ilmu umum pada akhirnya mampu merespon segala bentuk permasalahan pengembangan ekonomi Islam, sehingga keberadaan lembaga keuangan syariah terus mendapatkan kepercayaan publik.

Untuk itu, langkah strategis yang dapat di lakukan oleh perguruan tinggi untuk melaksanakan program pendidikan ekonomi Islam agar outputnya dapat memenuhi kebutuhan dari ilmu ekonomi Islam, diantaranya:

Pertama, memfasilitasi tenaga pengajar ke jenjang pendidikan yang lebih tinggi, secara rutin mengirimkan para staf pengajar untuk mengikuti pelatihan, seminar, workshop maupun pendidikan terkait ekonomi Islam. 
Selamat Muliadi: Epistemologi Ekonomi Islam...

Kedua, melakukan standarisasi kurikulum untuk ekonomi Islam tingkat nasional, standarisasi ini bukan berarti kurikulum seluruh perguruan tinggi harus sama melainkan ada kesepakatan mengenai kompetensi dasar minimal.

Ketiga, memperbanyak riset tentang ekonomi Islam, baik yang berskala mikto maupun makro, mendorong penulisan kajian dan karya ilmiah melalui penerbitan buku, jurnal ilmiah, seminar dan lokakarya.

Keempat, memperkuat berbagai sarana dan prasana pembelajaran baik yang bersifat teknis, seperti pengadaan untuk lcd proyektor, komputer, wi-fi dan pengadaan laboratorium praktik bagi mahasiswa.

Kelima, mengembangkan networking yang lebih luas dengan berbagai institusi pendidikan ekonomi Islam, lembaga keuangan dan non-keuangan Islam, baik di dalam maupun luar negeri.

\section{KESIMPULAN}

Dasar ilmu pengetahuan Islam adalah pendangan hidup Islam itu sendiri. Ilmu tidak muncul dai "hampa budaya" atau budaya yang tidak memiliki latar belakang epistemologi atau tanpa worldview. Di dalam bidang ekonomi Islam, penerapan epistemologi adalah dengan memasukkan nilai (etika) yang diambil dari worldview Islam ke dalam ekonomi mainstream. Teori ekonomi Islam yang oleh sebagian ilmuan dan ekonom Muslim diklaim sudah merupakan disiplin ilmu yang absah (valid) secara epistemologi dan merupakan sistem ekonomi siap dioperasionalkan, ilmu ekonomi yang baru lahir dalam abad modern. Teori ekonomi lahir di tengah-tengah masyarakat dunia yang sudah didominasi oleh sistem ekonomi kapitalis yang sudah ada lebih dulu. Sistem ekonomi Islam ini mendapat kritik epistemologi dari kalangan positifis yang berkisar pada validitas ilmu ekonomi Islam secara epistemologi, mengingat ilmu ini tidak pernah actual dalam sejarahnya atau hanya sekedar gagasan konsep saja.

Adapun sumber-sumber dari ilmu ekonomi Islam adalah sama dengan sumbersumber dalam hukum Islam sebagai otoritas beragama. Disamping juga mengacu kepada sumber-sumber nash juga sumber-sumber fiqh. Dalam rangka menggali asas atau prinsip umum yang akan menjadi ruh semua sektor ekonomi ini secara umum menerapkan metode induktif tematik. Adapun dalam rangka penerapan asas tersebut 
Islamiconomic: Jurnal Ekonomi Islam Vol.9 No.2 Juli - Desember 2018

ke dalam faktor barang dan jasa menggunakan metode deduktif. Dengan melihat sumber dan metode perumusan konsep ilmu ekonomi Islam, akan lebih fleksibel dalam mengiringi dinamika sosial-ekonomi manusia. Dalam rangka uji validitas, sebagaimana dalam semua disiplin ilmu keislaman, ilmu ekonomi ini menggunakan teori kebenaran komprehensip. Ilmu ekonomi Islam sudah dapat disebut sebagai ilmu pengetahuan absah secara epistemologi, mengingat sudah memenuhi standar ilmiah.

Pembelajaran ekonomi Islam dengan berbagai macam konsentrasi pada Perguruan Tinggi Agama Islam telah berlangsung lebih kurang satu dasawarsa. Untuk memenuhi keinginan pasar, PTAI perlu merekonstruksi model kurikulum, yakni dengan berusaha memberikan penekanan dan memadukan secara integratif terhadap aspek ilmu syariah dan aspek ilmu ekonomi. Di dalam pengembangan lembaga pendidikan ekonomi Islam ke depan, ada beberapa hal sangat penting untuk dikembangkan, yaitu menerapkan kurikulum yang mengintegrasikan ilmu ekonomi dengan ilmu ekonomi Islam secara berkelanjutan.

\section{PUSTAKA ACUAN}

Akram, Muhammad. "Methodology of Islamic Economics,". Journal of Islamic Economics, vol.1, No. 1, August 1987, Malaysia: International Islamic University Malaysia.

Amalia, Euis., Rianto, Nur. “ Kesesuaian Pembelajaran Ekonomi Islam di Perguruan Tinggi Dengan Kebutuhan SDM pada Industri Keuangan Syariah di Indonesia. Jurnal Inferensi, Vol. 7, No. 1, Juni 2013, Jakarta: UIN Syarif Hidayatullah.

Anshori, Isa. "Maqāṣid Al-Syariah Sebagai Landasan Etika Global". Jurnal Hukum Islam, Vol. 01, No. 01, Maret 2009, Surabaya: Universitas Muhammadiyah Surabaya.

'Audah, Jasser. Maqasid asy-Syariah as Philosophy of Islamic Law: A System Approach. London: The International Institute of Islamic Thought, 2008.

'Audah, Jaser. Al-Maqashid Untuk Pemula, alih bahasa, Ali 'Abdelmon'im, judul terjemahan. Yogyakarta: Suka Press, 2013.

Chapra, Umar. The Future of Economics: an Islamic Perspective. Leicester: Islamic Foundation, 2000.

Colander, David. Economics Eighth Edition. United States : McGraw-Hill Irwin, 2010. 
Selamat Muliadi: Epistemologi Ekonomi Islam...

Kattsoff, Louis. Pengantar Filsafat. Yogyakarta: Tiara Wacana Yogya, 1992.

Kholis, Nur. "Membedah Konsep Ekonomi Islam". Jurnal La_Riba, Vol. 3, No. 2, Desember 2009, Yogyakarta: Universitas Islam Indonesia.

Kuntowijoyo. Islam sebagai Ilmu: Epistemologi, Metodologi dan Etika. Yogyakarta: Tiara Wacana, 2006.

Mughits, Abdul. "Epistemologi Ilmu Ekonomi Islam”. Jurnal Hermeneia, Vol. 2, No. 2, Juli-Desember 2003, Yogyakarta: UIN Sunan Kalijaga.

Mustansyir, Rizal. Ilmu Filsafat. Yogyakarta: Pustaka Pelajar, 2002.

Pusparini, Martini Dwi. “Konsep Kesejahteraan Dalama Ekonomi Islam Perspektif Maqasid Syariah". Islamic Economics Journal, Vol. 1, No. 1, Juni 2015, Yogyakarta: Universitas Islam Indonesia.

Sanrego, Yulizar. "Membangun Konstruksi Keilmuan Ekonomi Islam”. Jurnal Islamica, vol. 5, No. 1, September 2010, Surabaya: UIN Sunan Ampel.

Sukmadinata, Nana Syaodih. Pengembangan Kurikulum: Teori dan Praktek. Bandung: Remaja Rosda Karya, 2005.

Syaparuddin. "Rekonstruksi Pembelajaran Ekonomi Islam pada Perguruan Tinggi Agama Islam". Jurnal At-Taradhi, Vol. 3, No. 1, Juni 2012, Watampone: Sekolah Tinggi Agama Islam Negeri Watampone

\section{Catatan Akhir:}

\footnotetext{
${ }^{1}$ Nur Kholis, "Membedah Konsep Ekonomi Islam” Jurnal La_Riba, Vol. 3, No. 2 (Desember 2009), hlm. 269-270.

${ }^{2}$ Syaparuddin, "Rekonstruksi Pembelajaran Ekonomi Islam pada Perguruan Tinggi Agama Islam", Jurnal At-Taradhi, Vol. 3, No. 1 (Juni 2012), hlm. 12-13.

${ }^{3}$ Euis Amalia dan M. Nur Rianto, “ Kesesuaian Pembelajaran Ekonomi Islam di Perguruan Tinggi Dengan Kebutuhan SDM pada Industri Keuangan Syariah di Indonesia, Jurnal Inferensi, Vol. 7, No. 1 (Juni 2013), hlm. 135. 2000), hlm. 125.

${ }^{4}$ Umar Chapra, The Future of Economics: an Islamic Perspective (Leicester: Islamic Foundation,

${ }^{5}$ Ibid, hlm. 126.

${ }^{6}$ Jasser 'Audah, Maqasid asy-Syariah as Philosophy of Islamic Law: A System Approach, (London: The International Institute of Islamic Thought, 2008), hlm. 2.

${ }^{7}$ Jaser 'Audah, Al-Maqashid Untuk Pemula, alih bahasa, Ali 'Abdelmon'im, judul terjemahan, (Yogyakarta: Suka Press, 2013), hlm. 4

${ }^{8}$ Martini Dwi Pusparini, “Konsep Kesejahteraan Dalama Ekonomi Islam Perspektif Maqasid Syariah”, Islamic Economics Journal, Vol. 1, No. 1 (Juni 2015), hlm. 54.

"Isa Anshori, "Maqāșid Al-Syariah Sebagai Landasan Etika Global”, Jurnal Hukum Islam, Vol. 01, No. 01, (Maret 2009), hlm. 16.

${ }^{10}$ Kuntowijoyo, Islam sebagai Ilmu: Epistemologi, Metodologi dan Etika (Yogyakarta: Tiara Wacana, 2006), hlm. 17.
} 
Islamiconomic: Jurnal Ekonomi Islam Vol.9 No.2 Juli - Desember 2018

\footnotetext{
${ }^{11}$ Abdul Mughits, "Epistemologi Ilmu Ekonomi Islam”, Jurnal Hermeneia, Vol. 2, No. 2 (JuliDesember 2003), hlm. 189-190.

${ }^{12}$ Muhammad Akram, "Methodology of Islamic Economics,", Journal of Islamic Economics, vol. 1, No. 1, (August 1987), hlm. 19.

${ }^{13}$ Rizal Mustansyir, Ilmu Filsafat, (Yogyakarta: Pustaka Pelajar, 2002), Hal 50

${ }^{14}$ David Colander, Economics. Eighth Edition, (United States of America : McGraw-Hill Irwin, 2010), hlm. 84.

${ }^{15}$ Louis Kattsoff, Pengantar Filsafat (Yogyakarta: Tiara Wacana Yogya, 1992), hlm. 191.

${ }^{16}$ Yulizar Sanrego, "Membangun Konstruksi Keilmuan Ekonomi Islam”, Jurnal Islamica, vol. 5, No. 1, (September 2010), hlm. 187.

${ }^{17}$ Nana Syaodih Sukmadinata, Pengembangan Kurikulum: Teori dan Praktek, (Bandung: Remaja Rosda Karya, 2005), hlm. 89.
} 